\title{
Using mathematical criteria of evaluation for diagnostics results of cadets' training in affective sphere
}

\author{
Palevych S.V., Piddubny O.G., Tkachuk O.A., Tzymbaliuk Z.O. \\ Ivan Kozhedub Kharkiv National Air Force University, Kharkiv, Ukraine
}

DOI: https://doi.org/10.34142/HSR.2019.05.01.11

\begin{abstract}
Objective: substantiation of the expediency of using mathematical evaluation criteria for determining the means of diagnosing a set of knowledge, skills and other competences acquired during the training of military men in the emotional (affective) sphere. Material: the study was attended by 67 cadets of the Air Force University, who are not the pilots and are at the 3rd year of study. For assessing the ability to manage their behavior through management of emotions, a technique of studying the emotional intelligence of military personnel at different stages of training and physical tests are related to overcoming objective and subjective obstacles. For the processing of the results was used the method of correlation, discriminant analysis and decision tree methods for the classification problem. The significance level for all statistics was established at $p<0.05$. Results: A positive linear relationship between the levels of performance of special exercises and the level of emotional stability were established. The models of discriminant analysis and the rule of classification of the recognition of the level of emotional stability according special physical preparedness level are determined. It was established that exercises in the obstacles course and turns in the gymnastics wheel are the main variables that allow classifying the students according to the level of emotional stability. Conclusions: The using of mathematical criteria for evaluating the results of the implementation of special exercises can differentiate according to the objective characteristics of cadets in category and simplifies the methodological work on recognition in the dynamics of physical improvement of military personnel, a local assessment of emotional and volitional resistance to the negative impact of the factors of modern combat. Keywords: emotional and volitional resistance, cadets, learning outcomes, special physical training.
\end{abstract}

\section{Анотація}

Палевич С.В., Піддубний О.Г., Ткачук О.А., Цимбалюк Ж. О. Використання математичних критеріїв оцінки для діагностики результатів навчання курсантів в афективнії сфері. Mema: обґрунтування доцільності використання математичних критеріїв оцінки для визначення засобів діагностики сукупності знань, умінь, навичок, інших компетентностей, що набуваються у процесі навчання військовослужбовців в емоційній (афективній) сфері. Матеріал: у дослідженні взяли участь 67 курсантів військового університету Повітряних Сил не льотного складу 3-го курсу навчання. Для оцінки вміння керувати своєю поведінкою за допомогою управління емоціями використовувалась методика вивчення емоційного інтелекту військовослужбовців на різних етапах підготовки та фізичні тести, що пов'язані з подоланням об'єктивних і суб'єктивних перешкод. Для обробки результатів використано метод кореляційного, дискримінантного аналізу та метод дерев рішень для задачі класифікації. Рівень значимості для всієї статистики був встановлений при р <0,05. Результати. Встановлено позитивний лінійний взаємозв'язок між рівнями виконання спеціальних вправ та рівнем емоційної стійкості. Визначено моделі дискримінантного аналізу та правило класифікації розпізнавання рівня емоційної стійкості за рівнем спеціальної фізичної підготовленості. Встановлено, що вправи на смузі перешкод та оберти на гімнастичному колесі $є$ головними змінними, які дозволяють класифікувати курсантів за рівнем емоційної стійкості. Висновки. Використання математичних критеріїв оцінки результатів виконання спеціальних вправ дозволяє диференціювати за об'єктивними ознаками курсантів по класам і спрощує методичну роботу з розпізнавання в динаміці фізичного вдосконалення військовослужбовців, локальну оцінку емоційно-вольової стійкості до негативного впливу факторів сучасного бою.

Ключові слова: емоційно-вольова стійкість, курсанти, результати навчання, спеціальна фізична підготовка

\section{Аннотация}

Палевич С.В., Поддубный А.Г., Ткачук А.А., Цимбалюк Ж.А. Использование математических критериев оценки для диагностики результатов обучения курсантов в афективной сфере. Цель: обоснование целесообразности использования математических критериев оценки для определения средств диагностики совокупности знаний, умений, навыков, других компетенций, приобретаемых в процессе обучения военнослужащих в эмоциональной (аффективной) сфере.Материал: в исследовании приняли участие 67 курсантов военного университета Воздушных Сил не летного состава 3-го курса обучения. Для оценки умение управлять своим поведением с помощью управления эмоциями использовалась методика изучения эмоционального интеллекта военнослужащих на различных этапах подготовки и физические тесты, связанные с преодолением объективных и субъективных препятствий. Для обработки результатов использован метод корреляционного, дискриминантного анализа и метод деревьев решений для задачи классификации. Уровень значимости для всей статистики был установлен при $p<0,05$. Результаты. Установлено позитивная линейная взаимосвязь между уровнями выполнения специальных упражнений и уровнем эмоциональной устойчивости. Определены модели дискриминантного анализа и правило классификации распознавания уровня эмоциональной устойчивости по уровню специальной физической подготовленности. Установлено, что упражнения на полосе препятствий и обороты на гимнастическом колесе являются главными переменными, которые позволяют классифицировать курсантов по уровню эмоциональной устойчивости. Выводы. Использование математических критериев оценки результатов выполнения специальных упражнений позволяет дифференцировать по объективным признакам курсантов по классам и упрощает методическую работу по распознаванию в динамике физического совершенствования военнослужащих, локальную оценку эмоционально-волевой устойчивости к негативному воздействию факторов современного боя. Ключевые слова: эмоционально-волевая устойчивость, курсанты, результаты обучения, специальная физическая подготовка. 


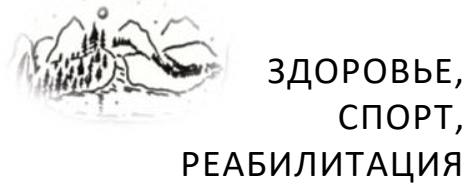

Introduction

Recently, the theme of mental stability and psychological readiness for action in battle has gained wide popularity in the researches of both Ukrainian and foreign scientists. The analysis of scientific publications showed that in extremely dangerous, difficult conditions of conducting military operations, military men feel affective fear (animal fear) - the strongest fear that paralyzes the ability to voluntary actions for some time (Gabriel', 1986; Bonn, \& Baker, 2000; Tyurin, 2002; Aga€v, 2014).

Scientists (Marishchuk, 1982; Makarov, Niznij, \& Shishkin, 2000; Leont'ev, 2016) consider psychological training in two aspects: psychological and pedagogical. The psychological aspect of the problem lies in the creation of a certain mental state in which servicemen are in constant combat readiness. The study of the mental state and its regulation in the process of combat activity consist within the competence of military psychology. Pedagogical aspect is the search for methodical techniques and ways for forming a certain mental state. Pedagogical techniques of psychological training are also used in the process of mastering the discipline "Special physical training" through the acquisition of appropriate competencies.

The level of competence development is determined by the results of learning (RL) in the emotional sphere. The conducted analysis of literature showed that today's studies devoted to studying the results of training in the affective sphere, are not enough, the structure and dynamics of their development aren't developed. As a rule, separate aspects of motives, psychological training, education of military men in the process of physical education and special physical training are studied (Zamana et el., 2012).

A number of scientific works were devoted to the physical preparation of this problem (Gusak, \& Romanchuk, 2011; Aga€v, 2014; Batrak, 2014), which solve the issues in general terms. Insufficient scientific and methodological development of issues of assessing the psychological readiness of military personnel in the process of exercising negatively affects the effectiveness of practical training (Romanchuk, 2015).

In Ukraine, in the XXI century when studying the problems of the affective sphere, a study of emotional intelligence (EI) (Petrovskaya, 2007) and its functions (Nosenko, \& Kovriga, 2003) appeared; studying the EI as determinants of internal freedom of the individual (Berezyuk, 2008), indicator integral its development (Roberts, Mett'yus, Zajdner, \& Lyusin, 2004) as a capacity for successful self-realization (Al€ksє€nko, Basyuk, \& Bezpal'ko,

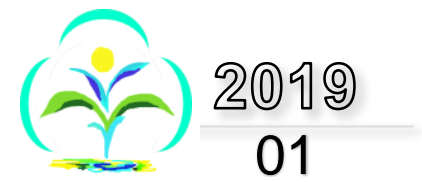

2008) and as emotional stability (Derevyanko, 2008; Palevich, Poddubny, Tkachuk, \& Tsimbalyuk, 2019).

Accordingly, it is relevant to use mathematical methods to analyze the questionnaire of emotional intelligence and to test the level of special physical fitness in order to restore interdependencies between factors that characterize the emotional stability of the soldier.

Possibilities of application of mathematical methods of analysis in various areas of physical culture are investigated in works devoted to the search of the method of mathematical modeling of the process of physical education, taking into account the complex training loading and the nature of the training loading (Lopatiev, Ivashchenko, Khudolii, Pjanylo, Chernenko, \& Yermakova, 2017), search of informative criteria of functional state (FS) of an organism, psychological status of athletes (Lalanne, Falissard, Golse, \& Vaivre-Douret, 2012; Kozina, \& Iermakov, 2015), biomechanical analysis of the technique of the athlete's movement, the design of tactical schemes for the conduct of the sporting fight (Zaitsev, Bessonov, Brezhnev, \& Sazonov, 2008; Dercole, Dercole, Gobbi, \& Gobbi, 2013). The most common methods are multidimensional statistical analysis (Orekhov, \& Karavaeva, 2005; Kashuba, Hmel'nic'ka, \& Nasralla, 2007).

Hypothesis: It was assumed that the using of mathematical evaluation criteria would allow to predict more accurately the results of military training in the affective area and increase the effectiveness of special training of military personnel.

The aim of the study: substantiation of the expediency of using mathematical evaluation criteria for determining the means of diagnosing a set of knowledge, skills and other competences acquired during the training of military men in the emotional (affective) sphere.

\section{Material and methods}

Participants. The study was attended by 67 cadets of the military university of the 3rd year of study, including 27 combatants. Including 60 cadets of the first and 7 th of the second age group. All participants in the study agreed to participate in the experiment.

Organization of research. The research was conducted during the 2017-2018 curriculum year.

To assess the ability to manage our behavior by managing emotions, we chose a technique for studying the emotional intelligence (EI) of servicemen at different stages of preparation, and 


\section{ЗДОРОВЬЕ, \\ СПОРТ, \\ РЕАБИЛИТАЦИЯ}

physical tests related to overcoming objective and subjective obstacles.

As a questionnaire for the evaluation of EI, the method by D.V. Lucina (Fetiskin, Kozlov, \& Manujlov, 2002) was chosen, the basis of which is the idea of the emotional intelligence as a mixed construct that combines cognitive abilities and personality characteristics (curiosity to the inner world of people, the tendency to psychological analysis of behavior, etc.). It consists of 30 statements and contains 5 scales:

1. Emotional awareness (EA).

2. Managing Emotions (ME)

3. Self-motivation (SM).

4. Empathy (Emp).

5. Recognition of the other people emotions

(PE).

The response form gives the following options for evaluating the statements: "fully agrees," "totally disagree," "mostly agrees," "mostly disagrees." In this case, one half of the points has a positive code, the other one is negative.

The result is calculated using the key. The obtained indicators allow to determine the level of emotional intelligence in general and its components: "high", "medium", "low".

The survey was conducted through the use of Google Forms to respondents.

For an objective assessment of the level of physical fitness, based on expert assessment, physical exercises that demand from the soldiers the emotional stability (overcoming the obstacles course in complicated conditions), confidence in their strength and purposefulness, courage and determination (exercises on special equipment) persistence and perseverance, endurence and selfcontrol (running on long distances, throwing grenades for goals). During the control exercises, various situations were introduced that forced the soldiers to show their intellectual and physical efforts while performing the task (explosive packets, signal missiles, bad weather conditions, changing conditions during their execution).

Exercise № 1. General control exercises on a general obstacles course. Performed without weapons. The distance is $400 \mathrm{~m}$. The starting position is standing in the trench. For the "GO" order, throw a grenade $\mathrm{F} 1$ from the trench at $20 \mathrm{~m}$ along the brick wall (breaks) or in area $(2.6 \mathrm{~m} \times 1 \mathrm{~m})$ in front of the wall; jump out of the trench and run $100 \mathrm{~m}$ along the trail towards the line of the beginning of the lane; run the flag and jump over a width of $2.5 \mathrm{~m}$; run through the passages of the labyrinth; overcome the fence; climb up the vertical ladder on the second (curved) section of the destroyed bridge; run along the beams, jumping over the gap, and jump to the ground from

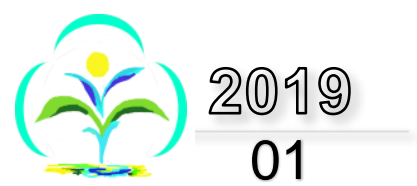

the position "standing" from the end of the last section of the beam; to overcome three stages of a damaged ladder and necessarily touch the two legs of the ground between the stages, to run under the fourth step; to break through the gap of the wall; jump into the trench; to go along the way; pop out of the well; to overcome the brick wall to the top; run the inclined ladder to the fourth stage and run along the steps of the damaged ladder; climb the vertical ladder to the bridge of the destroyed bridge; run along the beams, jumping over the gaps, and run down the sloping board; jump to a width of $2 \mathrm{~m}$, run $20 \mathrm{~m}$, run around the flag and run in the opposite direction $100 \mathrm{~m}$ along the path, finish.

Exercise № 2. Flick of a grenade F-1 for accuracy. Performed from a place or from a run with weapon in a hand. $0.5 \mathrm{~m} ; 2-1.5 \mathrm{~m} ; 3-2.5 \mathrm{~m}$. Grenades (16 pcs. - 4 for each distance). The distances to the goals are 20,25, 30, 35 м. The throws when you hit a grenade at the target are estimated: in 1 (central) circle - 10 points; in 2 - 6 points; in $3-4$ points.

Exercise № 3. Perform ten turns on a stationary gym wheel in either direction for time; the countdown is from the first vertical passage the top by the head.

Exercise № 4. The exercise with a basketball ball. The competitor begins to move from the face of the basketball court with the ball to the middle on the route between the obstacles, with the obligatory attack of both baskets until hit. The time is fixed by the whistle of the judge when the ball is completely hit in the ring of the basket, located on the side of the start.

Exercise № 5. Running $3 \mathrm{~km}$ with obstacles. Obstacles at the stadium are set up in $200 \mathrm{~m}$ and begin to overcome at the 3 rd circle. Clothing form № 4. Equipment: a rifle, the pounces for magazine banks, four magazine banks, a gas mask.

Exercise № 6. Special exercise with the gunfire. Performed without weapons. Standing position. Under the command "Start" take position lying, perpendicular to the line of motion. Overcome the distance of $25 \mathrm{~m}$, carrying out continuous twisting, without lifting the body and feet from the floor. Stand up and collect the weapon without touching the table, but not standing on the table with your hand or foot. Then carry out three shots of a pneumatic gun at the target at a distance of $10 \mathrm{~m}$, disassemble the weapon and return to run to the starting position. For each missed result a penalty of 5 seconds is added.

The result is the distribution of military personnel at the level of the EI and the assessment of their special exercises. 


\section{РЕАБИЛИТАЦИЯ}

Statistical analysis

Statistical data processing was performed using the Statistica 6 module Discriminant Analysis. Statistical processing of the material includes: the statistical data compilation, grouping of the primary material and the analysis of statistical indicators. The assessment of the type of distribution was carried out with the definition of the degree of central tendency between the arithmetic mean, fashion and median, as well as symmetry and excess (Bureeva, 2007).

Due to the fact that the standards of physical training tests are currently being revised, for the standardization of norms, the percentile method was used (Sergienko, 2010).

The study of the relationship between EA levels and special physical fitness is solved using correlation analysis methods:

measurement of the level of communication (positive, negative, linear, nonlinear);

establishing dependency forms;

selection of factors that are most interrelated and have a significant impact on the characteristics studied on the basis of measuring the degree of communication between phenomena.

A discriminant analysis was used to decide which physical exercises distinguish (discriminate) the servicemen on the level of emotional stability. To illustrate the possibilities of detecting hidden

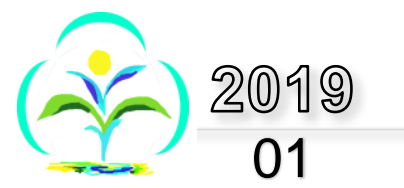

hierarchical patterns in relation to the data of the level of emotional stability and the level of special physical preparedness, the method of decision trees for the classification problem was used (Barsegyan et al., 2004).

\section{Results}

The conducted diagnostics using the questionnaire EMIN allowed to establish as an integrative index of emotional intelligence, as well as the level of manifestation of its individual components.

Thus, according to the questionnaire EMIN (Table 1), the vast majority of subjects show results that correspond to the average level of development of integral emotional intelligence (49.4 points). Similar values are observed on individual scales. Thus, the average indicator of the ability to understand the emotional state of a person on the basis of external manifestations of emotions (facial expressions, gesticulation, sound of the voice) and sensitivity to the internal states of other people (Emp); the ability to cause emotions in other people, in particular, to reduce the intensity of unwanted emotions is within the average level -9.1 and 8.91 points, respectively.

The results of diagnostics of emotional intelligence using the method of D.V. Lucina $(n=67)$

\begin{tabular}{lccc}
\hline \multirow{2}{*}{ Scale } & \multicolumn{3}{c}{ Level } \\
\cline { 2 - 4 } & High & Average & Low \\
\hline Emotional awareness & $20.90 \%$ & $38.80 \%$ & $40.30 \%$ \\
\hline Manage the emotions & $20.90 \%$ & $43.28 \%$ & $35.82 \%$ \\
\hline Self-motivation & $26.87 \%$ & $52.24 \%$ & $20.90 \%$ \\
\hline Empathy & $11.94 \%$ & $64.18 \%$ & $23.88 \%$ \\
\hline Recognizing of the other people emotions & $10.45 \%$ & $62.69 \%$ & $26.87 \%$ \\
\hline Integrative level of emotional intelligence & $10.45 \%$ & $62.69 \%$ & $26.87 \%$ \\
\hline
\end{tabular}

Significant differences are not observed in the ability to control emotions, nor in the ability to understand them. Ability to recognize and identify their own emotions, understanding their causes, the possibility of a verbal description of 9.93 points. An ability and a need to manage their emotions, invoke and maintain the desired emotions, keep control undesirable - 10,18 points. The ability to control external manifestations of their emotions is respectively 11.28 points, which corresponds to the average level.

Researchers of flight activity Marishchuk, (1982). Makarov, Niznij, Shishkin, (2000) mean the insusceptibility to emotionogenic factors under the emotional stability (along with the ability to control and restrain emerging asthenic emotions) and the ability to overcome the state of unnecessary emotional excitement when performing complex activities. Therefore, in our opinion, the calculation of subscales "Self-motivated" gives an idea of the level of manifestation of emotional stability $\left(\mathrm{E}_{\mathrm{st}}\right)$.

Below is a list of physical exercises that put high demands on the mental sphere of servicemen. In addition, in Table number 2 the average result of exercises with cadets with different levels of emotional stability is calculated. 


\section{ЗДОРОВЬЕ, \\ СПОРТ, \\ РЕАБИЛИТАЦИЯ}

Results of assimilation of physical exercises by cadets with different levels of emotional stability ( $n=67 ; x \pm m$, points)

\begin{tabular}{cccc}
\hline \multirow{2}{*}{ № Exercise } & \multicolumn{3}{c}{ Level of emotional stability } \\
\cline { 2 - 4 } & «High» & «Average» & «Low» \\
\hline Exercise №1 & $33.33 \pm 0.86$ & $26.60 \pm 0.62^{* *} ;\left(t_{\text {st. }}=6.37\right)$ & $16.07 \pm 2.5^{* *} ;\left(t_{\text {st. }}=4.09\right)$ \\
\hline Exercise №2 & $35.70 \pm 2.80$ & $27.20 \pm 2.51^{*} ;\left(t_{\text {st. }}=2.25\right)$ & $30.00 \pm 3.77$ \\
\hline Exercise №3 & $38.80 \pm 2.19$ & $23.40 \pm 1.87^{* *} ;\left(t_{s t .}=5.37\right)$ & $19.20 \pm 3.63$ \\
\hline Exercise №4 & $30.37 \pm 2.23$ & $28.11 \pm 2.49$ & $26.52 \pm 3.45$ \\
\hline Exercise №5 & $37.62 \pm 2.20$ & $24.33 \pm 2.41^{* *} ;\left(t_{s t .}=4.07\right)$ & $20.64 \pm 2.97$ \\
\hline Exercise №6 & $36.05 \pm 2.19$ & $23.10 \pm 2.48^{* *} ;\left(t_{s t .}=3.91\right)$ & $26.00 \pm 3.44$ \\
\hline
\end{tabular}

* At the level of significance $p<0.05$

$* * p<0.001$

Statistically significant difference is observed in all groups of cadets with different levels $\mathrm{E}_{\text {ст. }}$ when performing exercise № 1. Average results of exercises № 2, 3, 5, 6 statistically distinct only in groups with high and average levels statistically distinct only in groups with high and average levels $E_{\text {st. }}$. Differences in the results of exercise \# 4 are not observed in any of the groups.
Correlation-regression analysis (Table 3) shows. positively correlated average interconnection between levels of exercise № 1 and № 5 and a weak correlation between exercise № 3. With other exercises linear interconnection is not defined.

Scatter plot between exercise performance №1 and level $\mathrm{E}_{\text {ст }}$ confirms the positive relationship between variables, which is linear (Fig. 1).

Table 3

The matrix of correlations between the indicators of the special physical fitness level and the emotional stability level

\begin{tabular}{cccccccc}
\hline Indicator & Est. & $\begin{array}{c}\text { Exercise } \\
\text { №1 }\end{array}$ & $\begin{array}{c}\text { Exercise } \\
\text { №2 }\end{array}$ & $\begin{array}{c}\text { Exercise } \\
\text { №3 }\end{array}$ & $\begin{array}{c}\text { Exercise } \\
\text { №4 }\end{array}$ & $\begin{array}{c}\text { Exercise } \\
\text { №5 }\end{array}$ & $\begin{array}{c}\text { Exercise } \\
\text { №6 }\end{array}$ \\
\hline Est & 1.000 & $0.679^{*}$ & 0.127 & $0.292^{*}$ & -0.049 & $0.307^{*}$ & 0.217 \\
\hline ExerciseNo1 & $0.679^{*}$ & 1.000 & 0.150 & $0.252^{*}$ & -0.028 & $0.354^{*}$ & 0.154 \\
\hline ExerciseNo2 & 0.127 & 0.150 & 1.000 & 0.084 & 0.113 & $0.291^{*}$ & -0.099 \\
\hline ExerciseNo3 & $0.292^{*}$ & $0.252^{*}$ & 0.084 & 1.000 & -0.102 & 0.221 & $0.415^{*}$ \\
\hline ExerciseNo4 & -0.049 & -0.028 & 0.113 & -0.102 & 1.000 & 0.073 & -0.053 \\
\hline ExerciseNo5 & $0.307^{*}$ & $0.354^{*}$ & $0.291^{*}$ & 0.221 & 0.073 & 1.000 & 0.117 \\
\hline ExerciseNo6 & 0.217 & 0.154 & -0.099 & $0.415^{*}$ & -0.053 & 0.117 & 1.000 \\
\hline * $p<0.05$ & & & & & & & \\
\hline
\end{tabular}

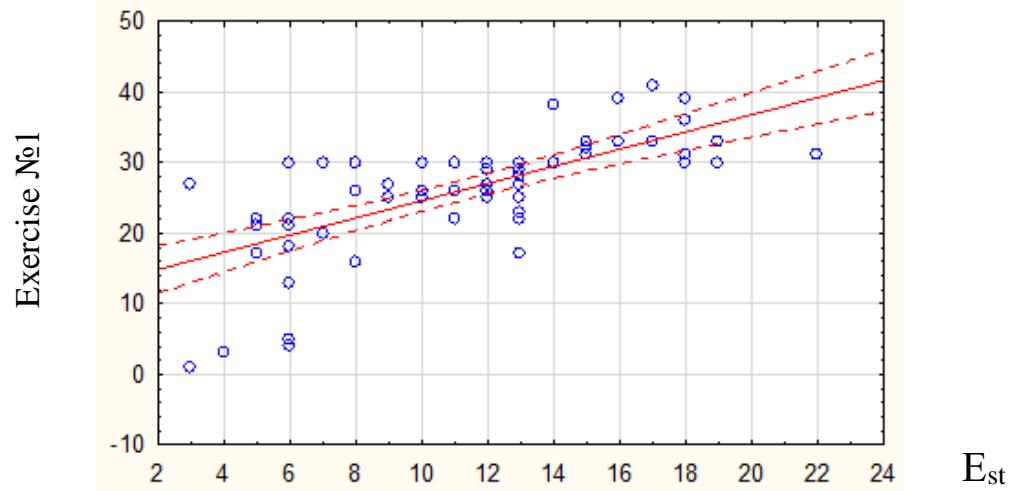

Fig.1. Diagram of dispersion between the results of the exercise №1 and level $\mathrm{E}_{\mathrm{st}}$ : $\mathrm{E}_{\mathrm{st}}$ - emotional stability

The evaluation of factors and the construction of models of interconnection between the level $E_{\text {ст }}$ and level APF confirm the existence of an average link between the levels of exercise № 1 and a weak link between exercises № 3 i № 5 (Table 4). 
Table 4

Analysis of the relationship between the indicators of the special physical fitness level and the emotional stability level

\begin{tabular}{ccc}
\hline Indicator & Kind of model & Correlation coefficient \\
\hline Exercise №1 & $\mathrm{E}_{s t}=1.345+0.379 \times$ ExNo1 & $r=0.679 ; \mathrm{R}^{2}=0.462$ \\
\hline Exercise №3 & $\mathrm{E}_{s t}=8.997+0.009 \times$ Ex№3 & $r=0.292 ; \mathrm{R}^{2}=0.085$ \\
\hline Exercise №5 & $\mathrm{E}_{\mathrm{st}}=8.888+0.093 \times$ ExNo5 & $r=0.307 ; \mathrm{R}^{2}=0.094$ \\
\hline
\end{tabular}

Notes: $E_{s t}$ - emotional stability; $r$ - correlation coefficient; $R^{2}$ - coefficient of determination.

The main characteristics of the discriminant analysis model of the level recognition $\mathrm{E}_{\text {ст }}$ according to the level of special physical fitness are in Table. 5. The value of the Wilbur Lambda in our case is equal to 0.352 and $\mathrm{F}$-criterion $\mathrm{F}(8.122)=$ 10.45 , which is more critical. From all the foregoing, we can conclude that this classification is practically correct.

The partial statistics of "lambda Wilkes" shows that the variable «Exercise № 1» reliably reflects the maximum contribution to general discrimination in the study of such individual components of emotional intelligence as "selfmotivated" (the lower its value, the greater the single contribution of the corresponding variable to the degree of discrimination). The remaining variables make a minimum contribution to general discrimination.

Results of discriminant analysis are presented in Table 5.

Results of discriminant functions analysis

Table 5

\begin{tabular}{ccccccc}
\hline N=67 & $\begin{array}{c}\text { lambda } \\
\text { Wilkes }\end{array}$ & $\begin{array}{c}\text { Partial } \\
\text { lambda }\end{array}$ & $\begin{array}{c}\text { F-exclusion } \\
(2.59)\end{array}$ & p-level & Tolerance & R-square \\
\hline & $\mathrm{E}_{\text {cr }}$ (lambda Wilkes: 0.352 approximately. $\left.\mathrm{F}(8.122)=10.45 \mathrm{p}<0.0000 ..\right)$ & \\
\hline Exercise №1 & 0.768 & 0.458 & 36.064 & 0.000 & 0.962 & 0.038 \\
\hline Exercise №3 & 0.387 & 0.910 & 3.028 & 0.056 & 0.848 & 0.152 \\
\hline Exercise №6 & 0.376 & 0.936 & 2.099 & 0.131 & 0.815 & 0.185 \\
\hline Exercise №2 & 0.371 & 0.948 & 1.677 & 0.195 & 0.941 & 0.059 \\
\hline
\end{tabular}

Table 6 lists the classification functions for selected groups of students with different levels $\mathrm{E}_{\mathrm{st}}$, which allow us to investigate the degree of interconnection between discriminant variables and the value of classification functions. Figure 2 shows a diagram of scattering of objects in the space of canonical roots.

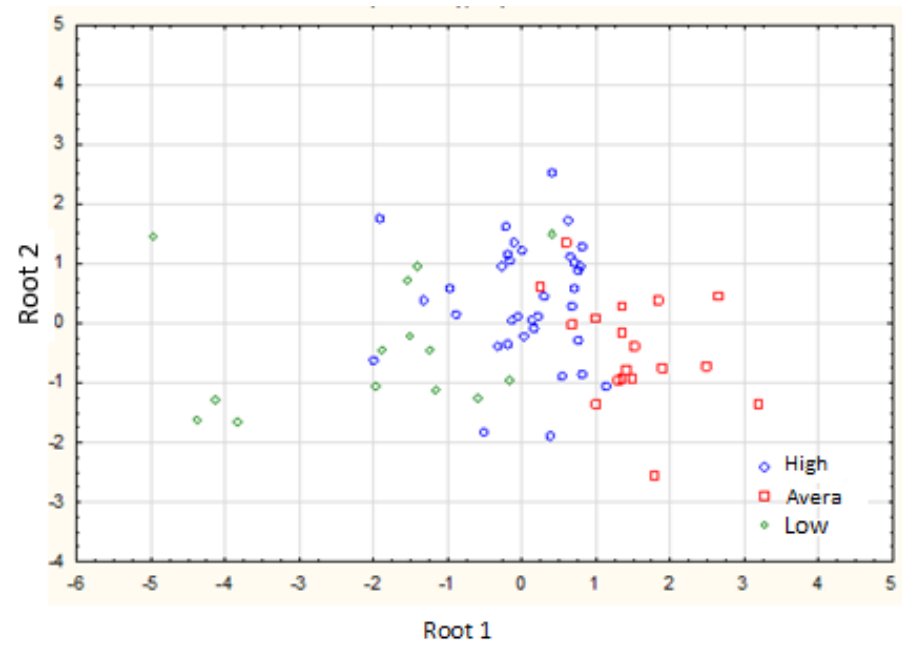

Fig. 2. Scattering diagram of objects in the space of canonical roots 
Classification functions for groups of objects by level $E_{s t}$

\begin{tabular}{cccc}
\hline Variable & Average $p=0.522$ & High $p=0.269$ & Low $\mathrm{p}=0.209$ \\
\hline Exercise №1 & 0.899 & 1.125 & 0.494 \\
\hline Exercise №3 & 0.119 & 0.173 & 0.065 \\
\hline Exercise №6 & 0.052 & 0.075 & 0.108 \\
\hline Exercise №2 & 0.096 & 0.122 & 0.140 \\
\hline Constant & -15.881 & -26.33 & -9.656 \\
\hline
\end{tabular}

Each classification function is a linear combination of effects with such coefficients. Note that the number of functions is equal to the number of levels of the dependent variable. In the given case there are three.

Each classification function has the following form:

$$
f_{i}=\sum_{j} a_{i j} x_{j}+a_{0}
$$

Where $f_{i}-i$ function of classification;

$x_{j}-j$ plan effect;

$a_{i j}$ - the coefficient of the i-th classification $a_{0}$ - free member.

Taking into account only the main effects (neglected by interactions), then the classification function for the dependent variable of the average level of self-motivation (emotional stability) in this case is taking the following form (the coefficients are taken from Table 6):

$$
f_{\text {average }}=\text { Exercise №1 } \times 0,899+\text { Exercise }
$$
№3 $\times 0,119+$ Exercise №6 $\times 0,052+$ Exercise №2

$$
\times 0,096-15,881
$$

Based on the same data, the indicators of the level of special physical training and the level of emotional stability classification trees were built (Figure 3 shows the resulting tree classification). function for the $j$-th effect of the plan;

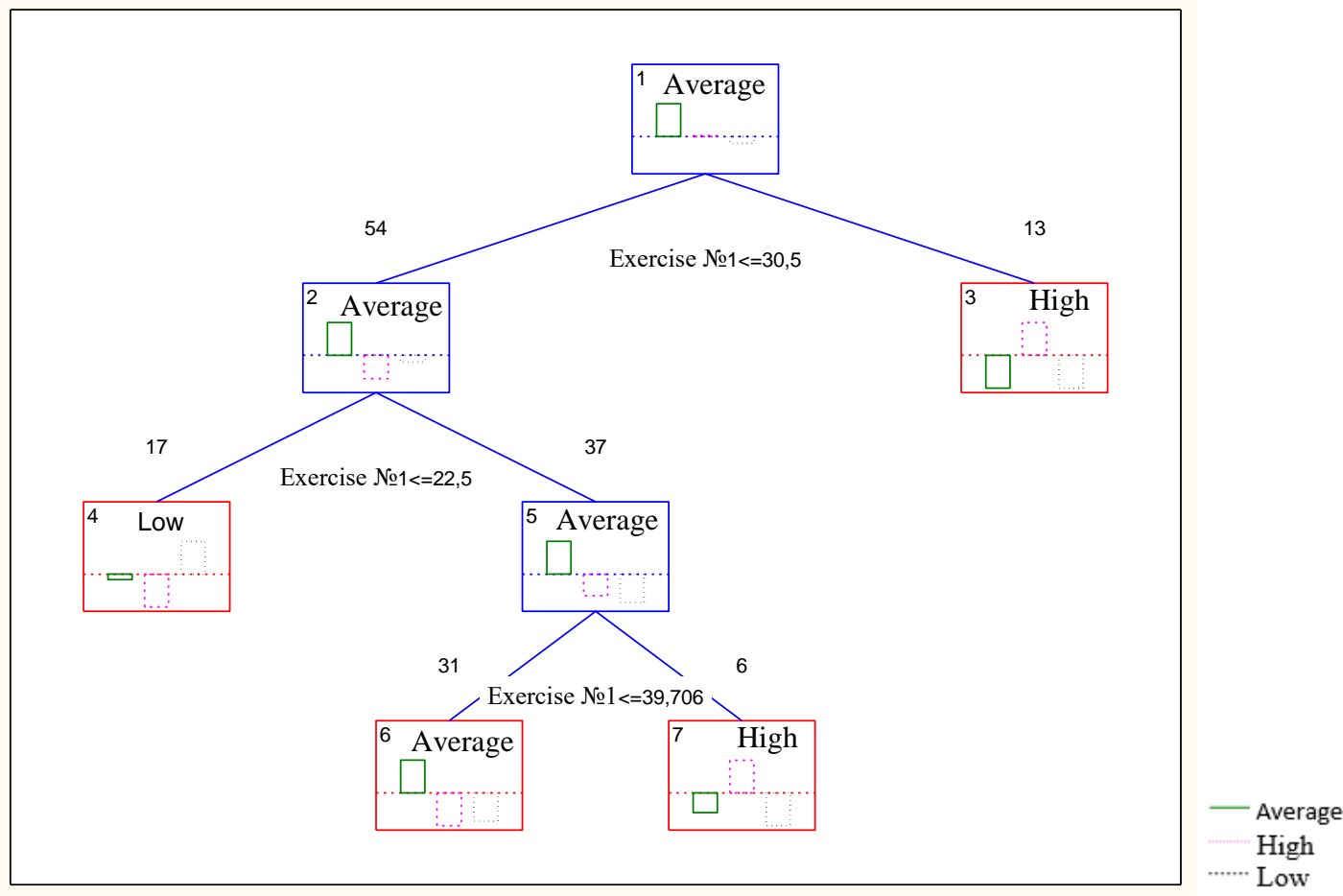

Fig. 3. Classification tree. Number of branches $=3$; number of terminal vertices $=4$

The resulting classification tree consists of decision-making nodes connected by ribs (Fig. 3). For each node of a tree there is a restriction on the value of the input variable, as well as the frequency histogram of the distribution of values of the predicted level EA.
Rules that classify servicemen by level EA in the Exel tab editor have the following form:

$=\mathrm{IF}$ (Exercise№1<=22,5;"Low"; $\operatorname{IF}(\mathrm{AND}(\mathrm{Ex}$ ercise№1<=30,5; Exercise№3<=39,706); "Average"; "High")) 


\section{ЗДОРОВЬЕ, \\ СПОРТ, \\ РЕАБИЛИТАЦИЯ}

To check the correctness of the training sample, look at the results of the classification matrix (Table 7, 8). Columns reflect predicted observations: the percentage of correctness for each group and the total percentage of adjustment across the sample. In addition, the number of objects assigned to this or that study sample group is indicated. The accuracy of

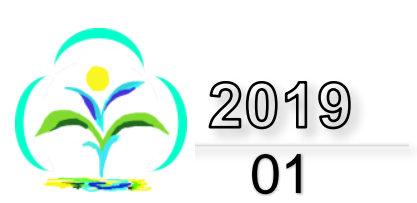

the overall classification is $77.612 \%$, for the average level $-85.571 \%$, for the low $-42.857 \%$. The accuracy of the overall classification is $88.06 \%$, for the average level $-93.548 \%$, for the low $-70.588 \%$.

Classification matrix of discriminant analysis

\begin{tabular}{ccccc}
\hline Level & Percentage of correctness & Average $-p=0.5224$ & High $-p=0.2687$ & Low $-p=0.2090$ \\
\hline Average & 88.571 & 31 & 2 & 2 \\
\hline High & 83.333 & 3 & 15 & 0 \\
\hline Low & 42.857 & 8 & 0 & 6 \\
\hline Total & 77.612 & 42 & 17 & 8 \\
\hline
\end{tabular}

Note: Lines are the observed results. Columns - predicted results

Table 8

The matrix of classification errors using the decision tree method

\begin{tabular}{ccccc}
\hline Level & Percentage of correctness & Average $p=0.5224$ & High $p=0.2687$ & Low $p=0.2090$ \\
\hline Average & 93.548 & 29 & 0 & 2 \\
\hline High & 94.737 & 1 & 18 & 0 \\
\hline Low & 70.588 & 5 & 0 & 12 \\
\hline Total & 88.060 & 35 & 18 & 14 \\
\hline
\end{tabular}

Note: Lines are the observed results. Columns - predicted results

\section{Discussion}

Analyzing the data on the formation of the servicemen mental readiness it should be noted that the similarity of the influence of trains and emotions on intellectual processes, their structural similarity on the part of physiology and the similarity of the influence on the psyche of feelings associated with wishes and emotions, makes it possible to distinguish these processes in the affective sphere of the psyche, the peculiarities of which can be determined through the results of learning in the affective sphere of personality (Leont'ev, 2016).

Since the management problems associated with the mental stability and psychological readiness for action in a battle are associated with the need for decision-making in a multifactorial environment, a multivariate analysis of the connection and the interdependence between factors which is required and which is difficult to explain only from the position of mental processes which are acting in the human psyche.

The research broadens the experience of the theory and practice of physical training of troops and proves that effective means of psychophysical training can and should be used by exercises from programs of military-applied sports that most adequately model military-professional actions of servicemen, which are connected with overcoming of objective and subjective obstacles (Oderov et al., 2017).

Consequently, the results of the study, both through the use of the survey and the examination of the level of special physical fitness (Table 1), confirm the results of previous studies, show the manifestation of the various levels of emotional intelligence and different levels of assimilation of physical exercises that need to be able to manage their actions with the help of managing emotions (Korolchuk, 2003; Zamana et al., 2012).

The results of physical exercising with cadets with different levels of emotional stability, correlation-regression analysis between the indicators of the special physical fitness level and the level of emotional stability (Table 2, 3, and 4) indicate the presence of an interesting pattern associated with the positive linear interconnection between levels of exercise № 1, 3, 5 and $\mathrm{E}_{\text {cr. The lack }}$ of interconnection with other exercises is due to the low level of exercise assimilation. The obtained results agree with the data of other researchers that warriors require not only the ability to withstand great nervous-psychic and physical activity, but requires the skillful possession of the technique of performing these exercises (Anatskyi, Kolomiitseva, \& Liubchich, 2018).

The analysis of the relationship between the indicators of the special physical fitness level and the 


\section{РЕАБИЛИТАЦИЯ}

emotional stability level depone that despite the difference of methods which were used, the results have a similar tendency (Table 4). Exercises that are not mastered by cadets do not demonstrate information about the development of emotional stability in the military.

Thus, soldiers with a high level of exercise № 1, 3, 5 show a high level $\mathrm{E}_{\text {st, }}$ which affects the level of combat readiness in general. Formation of the content of discipline requires taking into account this pattern, especially if one of the tasks of the PP determined formation of psychological readiness of soldiers.

These studies confirm the idea of a high informative potentials in the practical and research work to assess respondents of their abilities and features in the affective area. And the use of tests (physical exercises that put increased demands on the mental field) can establish an objective level of development of emotional sphere (Kolisnik, 2014).

Due to the fact that teachers of the Department of Physical Education carry out the continuous monitoring of the indicators of emotional stability of servicemen, the influence of emotional processes on the realization of their own individual abilities, which are based on subjective assessment (level of theoretical knowledge and practical skills, psychological and physical qualities), this study is limited to obtaining further results using mathematical evaluation criteria.

For the recognition and identification of the level of EA by the level of physical exercise, a method of stepwise discriminatory analysis (DA) was used using the Wilkes statistics as a criterion for the selection of the pre-grouped quantitative discriminatory variables.

When all the quantitative discriminant variables were classified, as a result of the application of DA were selected as the most informative of the four variables: exercise number 1 , 3, 6, 2 (Table 5). Results of D.A. show that the first (by significance) discriminant variable allows to distinguish between a priori groups with an average and a low level of EA the best way, and a third variable is a group with a high level of EA (Table 6).

The best indicator of the informativeness of the selected discriminant variables and the usefulness of using a discriminant function for interpreting intergroup differences is of course the percentage of correctly recognized objects using calculated discriminant functions (classification by level $\left.E_{s t}\right)$. The number of correctly recognized objects (both in general and in individual groups) indicates the conformity of a discriminant model with empirical data (Table.7). During the analysis it was found that the correctness of classification in the

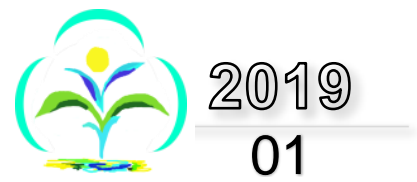

analysis was $77.61 \%$, this made it possible to correctly classify objects not included in the study sample in their respective groups with a probability of 0.78 .

The decision tree method allows you to obtain deciding rules in a consistent hierarchical form. In this case, the significance of the input variable is evaluated not for all objects of the training sample, but for each of the subsets formed as a result of branching the tree. According to Fig. 3 exercise number 1 is a the factor that has the strongest impact on the level of EA. This factor corresponds to the smallest criterion of partial statistics $\lambda=0,458$ (see Table 5) and as a result the value of this factor is checked at the root node of the tree.

There is a clear distinction between the tendency for the level of $\mathrm{E}_{\mathrm{st}}$ with the increase in the performance of exercise №1. In case if the result of exercise № 1 is more than 22.5 and does not exceed 30.5 points, the level of Est takes the value that corresponds to the average level of emotional stability. If a result of exercise number 1 less than 22.5 points, the level of $\mathrm{E}_{\mathrm{st}}$ takes the value that corresponds to a low level of emotional stability.

For a higher result (exercise number $1 \geq 30.5$ (points)) is characteristic, on the contrary, a high level of development of emotional stability. The high level of emotional stability is also determined by the result shown in exercise №3 $\geq 30.5$ and exercise number $1 \geq 22.5$ points.

It is interesting to emphasize that as a result of using the method of decision trees in the number of significant variables did not include such factors as exercise № 2, 6 .

The described tendency is quite natural. It is linked with the fact that the result in overcoming obstacles in the initial stage of training depends on the level of physical fitness and the degree of the formation of move skills. With increasing training, there is a comprehensive improvement of various functions of the body, improving coordination of all its systems and organs, control neurohumoral mechanisms of the central nervous system (Gusak, Romanchuk, \& Starchuk, 2008).

In this paper the approach to evaluating learning outcomes in the affective area with the use of mathematical evaluation criteria does not claim to be "perfect" and doesn't ultimately solve the problem of assessing military personnel. The practical necessity of solving this problem stimulates the constant search for new methods for assessing the totality of knowledge, skills and other competences acquired during the training of military men in emotional (affective) spheres.

Considered in the work version of the evaluation allows to some extent increase the 


\section{ЗДОРОВЬЕ, \\ СПОРТ, \\ РЕАБИЛИТАЦИЯ}

objectivity of the assessment compared with the control during psychological training (overcoming the psychological barrier obstacles). It has advantages such as: simplicity of assessment (reduction of cases of withdrawal from the route, disqualification when overcoming the band); shortening the time to check (up to 5 times); reducing the number of controllers; using of standard equipment, etc.

\section{Conclusion}

1. The method of questioning used to identify the ability to understand the person's relationship, represented in emotions and control the emotional sphere on the basis of decision-making, to a large extent allows to determine the level of emotional stability and the use of mathematical criteria for evaluating the results of special exercises will allow

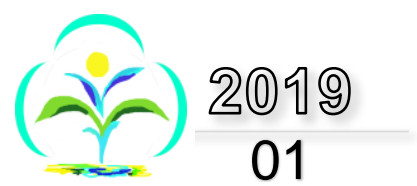

differentiating according to the objective characteristics of cadets in classes and thus simplify the methodological work on recognition in the dynamics of physical improvement of military personnel through a local assessment of the EA and a comprehensive assessment of the state of physical readiness.

2. The obtained data can become the basis for the next stage of work aimed at creating an information and analytical system for predicting the level of mental readiness of servicemen of different specialties and determining the level of the training results in the field of SPP in the affective area.

\section{Conflict of interest}

The authors argue that there is no conflict of interest.

\section{References}

1. Anatskyi, R., Kolomiitseva, O., \& Liubchich, R. (2018). The program of physical training of servicemen to a qualification examination on the right to wear the Beret with honors. Physical Education of Students, 22(6), 285-291. https://doi.org/10.15561/20755279.2018.0601

2. Bonn, K.E., \& Baker, A.E. (2000). Guide to Military Operations Other Than War. Tactics, Techniques and Procedures for Stability and Support Operations, Domestic and International. (pp. 13-17). Mechanicsburg (Penn.).

3. Dercole, A.A., Dercole, C., Gobbi, M., \& Gobbi, F. (2013). Technical, perceptual and motor skills in noviceexpert water polo players: an individual discriminant analysis for talent development. $J$ Strength Cond Res, 27(12), 3436-3444.

4. Lopatiev, A., Ivashchenko, O., Khudolii, O., Pjanylo, Y., Chernenko, S., \& Yermakova, T. (2017). Systemic approach and mathematical modeling in physical education and sports. Journal of Physical Education and Sport, 17(1), 146-155.

5. Oderov, A., Romanchuk, S., Fedak, S., Kuznetsov, M., Petruk, A., Dunets-Lesko, A., Lesko, O., \& Olkhovyi, O. (2017). Innovative approaches for evaluating physical fitness of servicemen in the system of professional training. Journal of Physical Education and Sport, 17 (1), 23 - 27

6. Agaev, N. (2014). Psychological problems of soldiers - ATO participants. Visnik MOU, 10, 8-9. In Ukrainian

7. Alekse€nko, T.F., Basyuk, T.P., Bezpal'ko, O.V. (2008). Social pedagogy: a small encyclopedia. K: Centr uchbovoï literaturi. In Ukrainian

8. Batrak, K. (2014). Problematic issues of psychological readiness of military personnel in conditions of combat activity. Materiali naukovometodichnoï konferenciï, 38-40. In Ukrainian

9. Berezyuk, G. (2008). Емоційний інтелект як детермінанта внутрішньої свободи особистості.

Psihologichni studï L'vivs'kogo universitetu, 2, 2023. In Ukrainian

10. Bureeva, N. (2007). Multivariate statistical analysis using SPT «STATISTICA». Nizhnij Novgorod. In Russian

11. Gabriel', R. (1986). Heroes are no more. Mental disorders and problems of military psychiatry in war. N'yu-Jork: Hilli Vong. In Russian

12. Gusak, O., \& Romanchuk, S. (2011). The role of physical training in solving the tasks of psychological training of servicemen. Problemi fizichnogo vihovannya $i$ sportu, 4, 61-64. In Ukrainian

13. Gusak, O., Romanchuk, S., \& Starchuk, O. (2008). Physical training in NATO's armed forces as a means of psychological readiness of servicemen for extreme conditions. Pedagogika, psihologiya ta medikobiologichni problemi fizichnogo vihovannya i sportu, 5, 138-141. In Ukrainian

14. Derev'yanko, S. (2008). Actualization of emotional intelligence in emotionogenic conditions. Social'na psihologiya, 1, 96-104. In Ukrainian

15. Zajcev, A.A., Bessonov, V.A., Brezhnev, YU.V., Sazonov, S.V. (2008). The program for assessing the adaptive capacity of a person to physical activity. Svidetel'stvo o gosudarstvennoj registracii programmy dlya EHVM № 2008611419 ot 20 marta $2008 \mathrm{~g}$

16. Zamana, V.M., Vorobjov, G.P., Tkachuk, P.P., Muzhenko, V.M., Kobers'kij, L.V., Bojko, O.V., \& Romanishin, A.M. (2012). Organization of psychological training of the personnel of the Army units. L'viv: ASV. In Ukrainian

17. Kashuba, V., Hmel'nic'ka, I., \& Nasralla, Z. (2007). Biomechanical and Information Technologies in Physical Education and Sports. Teoriya i metodika fizichnogo vihovannya i sportu, 2, 77. In Ukrainian

18. Kolisnik, L.O. (2014). Problem of diagnosing emotional intelligence Collection of scientific works of KPNU named after Ivan Ogienko, GSKostiuk 


\section{ЗДОРОВЬЕ, \\ СПОРТ, \\ РЕАБИЛИТАЦИЯ}

Institute of Psychology of the National Academy of Sciences of Ukraine. Problemi suchasnoï psihologii. Vol. 26, 278-295. In Ukrainian

19. Korol'chuk, M.S. (2003). Psychophysiology of activity. Kï̈v: El'ga Nika-Centr. In Ukrainian

20. Leont'ev, D.A. (2016). The concept of motive in A.N. Leontiev and the problem of quality motivation. Vestnik Moskovskogo universiteta, 2, 3-18. In Russian

21. Makarov, R.N., Niznij, N.A., \& Shishkin, Zh.K. (2000). Psychological foundations of flight composition didactics. Moskva. In Russian

22. Marishchuk, V. L. (1982). The study of mental and psychomotor qualities through exercise. Voennoprofessional'noe obuchenie $i$ fizicheskaya podgotovka, 2, 29-32. In Russian

23. Methods and models of data analysis: OLAP \& Data Mining. (2004). Barsegyan, A.A. i dr. SPb.: BHV Peterburg. In Russian

24. Nosenko, E., \& Kovriga, N. (2003). Emotional intelligence: the conceptualization of the phenomenon, the main functions. Kiïv: Vishcha shkola. In Ukrainian

25. Organizational and methodological instructions for the development of educational and professional programs, programs and work syllabuses on the educational discipline "Physical education, special physical training" for cadets and students of the Secondary School. Ukladach Suhorada G.I. Za red.

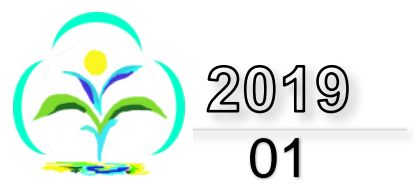

D.S. Grishchenka, YU.S. Finogenova. K.: MO Ukraïni. In Ukrainian

26. Orekhov, L., \& Karavaeva, E. (2005). On the necessity of complying statistical and experimental methods with modern requirements. Teoriya $i$ praktika fizicheskoj kul'tury, 3, 46-49. In Russian

27. Petrovskaya, A. (2007). Emotional intelligence as a determinant of performance parameters and procedural characteristics of management activities. Yaroslavl'. In Russian

28. Roberts, R., Mett'yus, Dzh. Zajdner, M., \& Lyusin, D. (2004). Emotional intelligence: problems of theory, measurement and application in practice. Psihologiya: Zhurnal Vysshej Shkoly Ekonomiki, 4, 3-24. In Russian

29. Romanchuk, S.V. (2015). Investigation of the physical preparedness of servicemen during combat operations. Naukovij chasopis. Naukovopedagogichni problemi fizichnoï kul'turi, 15, 3 (56), 316-319. In Ukrainian

30. Sergienko, L.P. (2010). Sports Metrology: Theory and Practical Aspects. Kiïv: KNT. In Ukrainian

31. Tyurin, D. (2002). Psychological operations of the US armed forces in Afghanistan. Zarubezhnoe voennoe obozrenie, 3, 7-11. In Russian

32. Fetiskin, N.P., Kozlov, V.V., \& Manujlov, G.M. (2002). Socio-psychological diagnosis of personal development and small groups. Moskva, Izdatel'stvo Instituta Psihoterapii. In Russian

\section{Информация об авторах}

\section{Палевич С.В.}

http://orcid.org/0000-0002-8304-1857

junpolpsv@gmail.com

Харківський національний університет Повітряних

Сил імені Івана Кожедуба

вул. Сумська 77/79, Харків, 61023

\section{Піддубний О.Г.}

http://orcid.org/0000-0002-4009-5070

poddubnyag@gmail.com

Харківський національний університет Повітряних

Сил імені Івана Кожедуба

вул. Сумська 77/79, Харків, 61023

\section{Ткачук О.А.}

\section{http://orcid.org/0000-0002-0790-4104}

alextkachuk@i.ua

Харківський національний університет Повітряних Сил імені Івана Кожедуба

вул. Сумська 77/79, Харків, 61023

\section{Цимбалюк Ж.о.}

http://orcid.org/0000-0002-9129-5689

tzymbaliuk.zhanna@yandex.ua

Харківський національний університет Повітряних Сил імені Івана Кожедуба

вул. Сумська 77/79, Харків, 61023

Принята в редакиию 16.09.2018

\section{Information about the authors}

Palevych S.V.

http://orcid.org/0000-0002-8304-1857

junpolpsv@gmail.com

Ivan Kozhedub Kharkiv National Air Force University

Sumska st. 77/79, Kharkiv, 61023

\section{Poddubny O.G.}

http://orcid.org/0000-0002-4009-5070

poddubnyag@gmail.com

Ivan Kozhedub Kharkiv National Air Force University

Sumska st. 77/79, Kharkiv, 61023

\section{Tkachuk O.A.}

http://orcid.org/0000-0002-0790-4104

alextkachuk@i.ua

Ivan Kozhedub Kharkiv National Air Force University

Sumska st. 77/79, Kharkiv, 61023

\section{Tzymbaliuk Z.O.}

http://orcid.org/0000-0002-9129-5689

tzymbaliuk.zhanna@yandex.ua

Ivan Kozhedub Kharkiv National Air Force University

Sumska st. 77/79, Kharkiv, 61023 